\title{
THE USE OF RADIOCARBON TO MEASURE THE EFFECTS OF EARTHWORMS ON SOIL DEVELOPMENT
}

\author{
J D STOUT* and $\mathrm{K}$ M GOH**
}

ABSTRACT. $\Delta^{14} \mathrm{C}$ and $\delta^{13} \mathrm{C}$ values for organic matter in forest and grassland soils, in the presence or absence of earthworms, indicate that it should be possible to quantify the effects of earthworms on soil organic matter by this means. Without earthworms, both in forest and grassland soils, plant debris tends to accumulate on the surface of the mineral soil and little organic matter is incorporated into or is translocated down the soil profile. Where earthworms are present, there is much more marked incorporation of fresh plant debris in the mineral soil. This is shown especially by the pulse of 'bomb' carbon and also by the $\delta^{13} \mathrm{C}$ values.

\section{INTRODUCTION}

Gilbert White, in "The Natural History of Selbourne" (1951), first drew attention to the role of earthworms in

boring, perforating, and loosening the soil, and rendering it pervious to rains and the fibres of plants, by drawing straws and stalks of leaves and twigs into it; and, most of all, by throwing up such infinite numbers of lumps of earth called worm-casts (Letter 35, May 20, 1770).

In 1837, Charles Darwin published a paper in the Transactions of the Geological Society of London "On the formation of mould". In this paper, he advanced the interpretation that the superficial layer of the soil was formed by the casting action of earthworms, which, incidentally, tended to bury stones and other objects. He claimed that, for one peaty field, a superficial layer of earthworm casts to a depth of almost $10 \mathrm{~cm}$ had been built up over a period of 15 years, and suggested that such activity also took place at a slower rate at greater depth. The activity of earthworms continued to interest him and in 1883 he published his book "The Formation of Vegetable Mould through the Action of Earthworms". Darwin's views have generally been endorsed (Edwards and Lofty, 1977), but although numerous estimates have been made of the rate of accumulation of surface casting, it has proved more difficult to evaluate the earthworm's role in the mixing and turnover of organic matter in deeper horizons of the soil. In temperate countries, where earthworms are normally the most important soil animals, their activity can be gauged by the evidence of worm burrows and casts, changes in color of the soil, and distribution of organic matter. It is difficult, however, to obtain quantitative data from these observations.

Earthworms show considerable specialization. They may be surface, topsoil, or subsoil dwellers (Lee, 1959). This specialization is related to size, activity, and food preferences. For those feeding on recent plant debris, the numbers and weight are related to the productivity of the vegetation (Waters, 1955). Although widespread in most temperate countries, the distribution of earthworms reflects geologic history. Apart from a small peregrine fauna, earthworms faunas tend to be endemic and closely related to prevailing ecological conditions. Where such condi-

* Soil Bureau, Department of Scientific and Industrial Research, Lower Hutt, New Zealand

** Lincoln College, Canterbury, New Zealand 
tions change, the native earthworms may disappear and they may be replaced by exotic species.

Radiocarbon provides a convenient means of obtaining quantitative data on the rate of accumulation, translocation, and turnover of organic matter in soil, particularly following enrichment by 'bomb' radiocarbon (Nakha and Delibrias, 1967; Rafter and Stout, 1970; O'Brien and Stout, 1978). Such data should also permit a quantitative assessment of the role of earthworms in these processes. In this paper, data is examined from forest and grassland soils.

\section{MATERIALS AND METHODS}

$\Delta^{14} \mathrm{C}$ and $\delta^{13} \mathrm{C}$ values were determined on whole soil samples from soil horizons, with and without earthworms. Samples were pretreated with $\mathrm{HCl}$ to remove carbonate, if present, before being analyzed.

\section{RESULTS AND DISCUSSION}

\section{Forest soils}

Data from two northern hemisphere hardwood stands are shown in table 1. In the Oxford soil (Phillipson and others, 1975; 1978), at one site where leaves and other plant litter tend to accumulate at the surface $(5$ to $0 \mathrm{~cm})$, only surface-dwelling earthworms are active. This plant material is enriched with 'bomb' radiocarbon incorporated into the leaves. The underlying mineral soil $(0$ to $10 \mathrm{~cm})$ has much less carbon and is very much older, showing no significant incorporation of 'bomb' radiocarbon. By contrast, an adjacent site, within a few meters, where earthworms are active in the mineral soil, has no surface litter accumulation. Fresh plant debris is rapidly incorporated into the topsoil (0 to $10 \mathrm{~cm}$ ), which is, consequently, richer in carbon and 'bomb' radiocarbon than the other topsoil. This is a shallow soil overlying coral limestone.

TABLE 1

Radiocarbon data for soils under forest

\begin{tabular}{|c|c|c|c|c|c|}
\hline $\begin{array}{l}\text { Soil depth } \\
\quad(\mathrm{cm})\end{array}$ & $\% \mathrm{C}$ & $\delta^{13} \mathrm{C}$ & $\begin{array}{c}\Delta^{14} \mathrm{C} \\
\% c\end{array}$ & $\begin{array}{l}\text { Radiocarbon } \\
\text { age (yr BP) }\end{array}$ & $\%$ Modern \\
\hline \multicolumn{6}{|c|}{$\begin{array}{l}\text { Brogden's Belt } \\
\text { Oxford, England* }\end{array}$} \\
\hline $\begin{array}{l}5-0 \\
0-10\end{array}$ & $\begin{array}{c}14 \\
6.5\end{array}$ & $\begin{array}{l}\text { Site w } \\
-27.0 \\
-25.8\end{array}$ & $\begin{array}{c}\text { topsoil wo } \\
+305 \pm 11 \\
-9 \pm 6\end{array}$ & & $\begin{array}{r}130 \pm 1 \\
99 \pm 1\end{array}$ \\
\hline \multicolumn{6}{|c|}{ Site with topsoil worms } \\
\hline $0-10$ & 9 & -26.6 & $+36 \pm 7$ & & $104 \pm 1$ \\
\hline \multicolumn{6}{|c|}{$\begin{array}{l}\text { Hubbard Brook, } \\
\text { New Hampshire, USA** }\end{array}$} \\
\hline $\begin{array}{l}20-9 \\
27-30 \\
44-60\end{array}$ & $\begin{array}{l}42 \\
2.6 \\
0.16\end{array}$ & $\begin{array}{l}-26.1 \\
-25.9 \\
-24.7\end{array}$ & $\begin{array}{r}-49 \pm 4 \\
-42 \pm 7 \\
-459 \pm 6\end{array}$ & $\begin{array}{c}390 \pm 30 \\
330 \pm 60 \\
5070 \pm 100\end{array}$ & $\begin{array}{l}95 \pm 0.4 \\
96 \pm 0.7 \\
54 \pm 0.6\end{array}$ \\
\hline
\end{tabular}

* Sampled June 1973, under beechwood.

** Sampled May 1977, under hardwood. 
At Hubbard Brook, in northeastern United States, earthworms were eliminated during the Pleistocene glaciation and the area has not yet been recolonized (Likens and others, 1977). The soil has developed under forest over weathering granite. It shows very slow incorporation of plant litter; a layer of surface litter that is more than $10 \mathrm{~cm}$ is not uncommon. This thick surface layer shows little enrichment by 'bomb' radiocarbon, indicating a very slow rate of turnover. Organic material from this surface horizon is translocated down the soil profile and accumulates, little changed, in the upper subsoil $(27$ to $30 \mathrm{~cm})$. There it may be enriched with younger material from roots and its radiocarbon age is consequently the same as the surface litter. Since the soil has only developed since the last glaciation, it is not more than 10,000 years old, but the mean age $(5070 \pm 100 \mathrm{yr}$ вP) of the organic matter in the lower subsoil $(44$ to $60 \mathrm{~cm})$ indicates, again, a very slow rate of turnover (table 1$)$. These figures contrast strongly with those of Rafter and Stout (1970) for a New Zealand hardwood forest site, where earthworms are present, and the litter, topsoil and subsoil show 'bomb' radiocarbon enrichment.

\section{Grassland soils}

Earthworms are commonly active in grassland soils of the temperate region, but where there is a marked change of vegetation there may also be a change in the earthworm fauna. In New Zealand, replacement of native vegetation normally leads to the disappearance of the native earthworm fauna, but the establishment of exotic European pastures is generally followed by the introduction of the European lumbricid earthworms (Lee, 1959).

In areas without earthworms, the soil is characterized by surface accumulation of undecomposed plant debris and by absence of marked incorporation of this organic matter into the lower mineral horizons.

TABLE 2

Grassland soils. Profiles under grazed pasture, Wehenga soil, Taieri, New Zealand (sampled February, 1977)

\begin{tabular}{|c|c|c|c|c|c|}
\hline $\begin{array}{l}\text { Soil depth } \\
\quad(\mathrm{cm})\end{array}$ & $\% \mathrm{C}$ & $\begin{array}{c}\delta^{19} \mathrm{C} \\
\% / \%\end{array}$ & $\begin{array}{c}\Delta^{14} \mathrm{C} \\
\% / c\end{array}$ & $\begin{array}{l}\text { Radiocarbon } \\
\text { age (yr BP) }\end{array}$ & $\%$ Modern \\
\hline \multicolumn{6}{|c|}{ Profile with introduced worms } \\
\hline $0-10$ & 4.9 & -27.8 & +194 & & 120 \\
\hline $10-18$ & 3 & -28.0 & +102 & & 110 \\
\hline $18-25$ & 1.1 & -26.9 & -22 & $170 \pm 40$ & 98 \\
\hline $25-40$ & 0.6 & -27.0 & -127 & $1100 \pm 50$ & 88 \\
\hline $40-59$ & 0.3 & -27.2 & -224 & $2070 \pm 80$ & 78 \\
\hline $59-73$ & 0.08 & -26.8 & -402 & $4230 \pm 90$ & 60 \\
\hline \multicolumn{6}{|c|}{ Profile without introduced worms } \\
\hline $3-0$ & 19 & -29 & +400 & & 140 \\
\hline $0-10$ & 3.5 & -27.5 & +89 & & 109 \\
\hline $10-17$ & 2 & -25.0 & -11 & $70 \pm 30$ & 99 \\
\hline $17-24$ & 1.1 & -26.2 & -62 & $510 \pm 40$ & 94 \\
\hline $24-40$ & 0.7 & -26.6 & -121 & $1050 \pm 50$ & 88 \\
\hline $40-56$ & 0.3 & -27.6 & -250 & $2360 \pm 70$ & 75 \\
\hline
\end{tabular}


An example is given in table 2. In the profile without introduced earthworms, there is accumulation of surface litter $(3$ to $0 \mathrm{~cm})$, enriched with 'bomb' radiocarbon, but less 'bomb' enriched organic matter has been incorporated into the top mineral horizons $(0$ to $20 \mathrm{~cm})$ than in the profile with introduced earthworms. With introduced earthworms, not only is there greater 'bomb' enrichment in the topsoil horizons, but there is also more organic matter incorporation, with considerable effect on porosity, structure, and water-holding capacity (Stout, Tate, and Molloy, 1976). Although this soil is of comparable age to that of the northeastern United States forest soil (ca 10,000 yr), organic matter at about $50 \mathrm{~cm}$ depth is only half the radiocarbon age $(2360 \pm 70 \mathrm{yr} \mathrm{BP})$, indicating the profound differences in organic cycling in different soils and with different plant and animal regimes (table 2).

Because of their effects on the physical properties of soils, earthworms accelerate the movement of organic matter both directly, by bringing material down into their burrows or casting at the surface, and indirectly, by increasing the macropore space and the rate of infiltration and percolation. The New Zealand grassland soil, developed under native tussock grasses with a native earthworm fauna including large and active subsoil species, shows an even and deep distribution of older organic matter. It is only the more recent organic matter, most clearly indicated by 'bomb' enrichment, that shows the limited movement and mixing in soils without earthworms.

The pulse of 'bomb' radiocarbon provides the most clear-cut evidence of differential movement. This evidence is substantiated by $\delta^{13} \mathrm{C}$ measurements. In grassland soil without earthworms, there is less young, lighter plant material incorporated into the mineral topsoil than in the soil with earthworms. This trend is also shown by the Oxford soil (table 1).

It is possible to construct models analyzing the relative importance of translocation, decomposition, and turnover in grassland soils ( $\mathrm{O}^{\prime}$ Brien and Stout, 1978), and consequently, it should be possible to quantify the importance of earthworms in soil organic matter movement and turnover.

\section{CONCLUSION}

Radiocarbon measurements, supplemented with $\delta^{13} \mathrm{C}$ values, indicate the relative importance of earthworms affecting soil structure, relative movement, and turnover of soil organic matter.

\section{ACKNOWLEDGMENTS}

The isotope determinations were carried out by $\mathrm{H} \mathrm{S}$ Jansen, $\mathrm{R} \mathrm{C}$ McGill, M K Burr, and R G Currie of the Radiocarbon Laboratory, Institute of Nuclear Sciences, Department of Scientific and Industrial Research, Lower Hutt, New Zealand.

We are indebted to J Phillipson, Animal Ecology Research Group, Oxford, for the opportunity to sample the Brogden Belt sites; to R S Pierce, North Eastern Forest Experiment Station, U S Department of Agriculture Forest Service, for the samples from Hubbard Brook; and to A Hewitt, Soil Bureau, New Zealand, for the grassland samples. 


\section{REFERENCES}

Edwards, C A and Lofty, J R, 1977, Biology of earthworms, 2nd ed: London, Chapman and Hall, $p 333$.

Lee, K E, 1959, The earthworm fauna of New Zealand: Wellington, New Zealand Dept Sci \& Indust Research Bull, v 130, p 486.

Likens, G, Borman, F H, Pierce, R S, Eaton, J S, and Johnson, N M, 1977, Biogeochemistry of a forested ecosystem: New York, Springer Verlag, p 146.

Nakha, S M and Delibrias, G, 1967, Utilisation du carbonne-14 d'origine thermonucleaire par l'étude de la dynamique du carbonne dans le sol, in Radiocarbon dating and methods of low-level counting: Vienna, I A E A, p 169-176.

O'Brien, B J and Stout, J D, 1978, Movement and turnover of soil organic matter as indicated by carbon isotope measurements: Soil Biol Biochem, v 10, p 309-317.

Phillipson, J, Abel, R, Steel, J, and Woodell, S R J, 1978, Earthworm numbers, biomass and respiratory metabolism in a beech woodland - Wytham Woods, Oxford: Oecologia (Berlin), v 33, p 291-309.

Phillipson, J, Putnam, J, Steel, J, and Woodell, S R J, 1975, Litter input, litter decomposition and evolution of carbon dioxide in a beech woodland: Oecologia (Berlin), v 20, p 203-217.

Rafter, T A and Stout, J D, 1970, Radiocarbon measurements as an index of the rate of turnover of organic matter in forest and grassland ecosystems in New Zealand, in Olsson, I U, ed, Radiocarbon variations and absolute chronology, Nobel symposium, 12th, Proc: Stockholm, Almqvist \& Wiksell, p 401-417.

Stout, I D, Tate, K R, and Molloy, L F, 1976, Decomposition processes in New Zealand soils with particular respect to rates and pathways of plant degradation, in The role of terrestrial and aquatic organisms in decomposition processes, in Symposium of the British Ecology Society, 17th: Oxford, Blackwell Sci Pub, p 95-144.

Waters, R A S, 1955, Numbers and weights of earthworms under a highly productive pasture: New Zealand Jour Sci Technol, v A36, p 516-525.

White, G, 1951, The natural history of Selbourne: London, Lutterworth Press, p 308. 